\title{
Peran Keluarga Sangat Penting dalam Pendidikan Mental, Karakter Anak serta Budi Pekerti Anak
}

\author{
Dyah Satya Yoga Agustin, Ni Wayan Suarmini, Suto Prabowo
}

\begin{abstract}
Abstrak
Pada tulisan ini diulas bahwa keluarga memiliki peranan penting dalam membentuk karakter seorang anak. Dalam dalam tulisan ditemukan bahwa sebagai suatu sistem sosial terkecil, keluarga menanamkan nilai-nilai moral dalam kepribadian seorang anak. Pada masa pertumbuhan, seorang anak memiliki banyak pertanyaan mengenai hal-hal yang dirasanya baru. Anak memiliki pertanyan-pertanyaan kritis, disinilah dituntut kemampuan komunikasi yang baik yang harus dimiliki oleh setiap orang tua dalam menjawab pertanyaan-pertanyaan yang dilontarkan oleh seorang anak. Keluarga sekarang memiliki fungsi yang lebih kompleks yang mencakup fungsi produksi serta konsumsi. Penulisan ini perlu dilakukan agar pembaca dapat memiliki pandangan bagaimana pengaruh keluarga terhadap perkembangan karakter seorang anak. Pada akhirnya dapat dikatakan bahwa keluarga memiliki peran yang sangat penting dalam membentuk karakter seorang anak.

Kata kunci : perkembangan karakter anak, sosiologi keluarga, psikologi anak.
\end{abstract}

Di semua masyarakat yang pernah dikenal, hampir semua orang hidup terikat dalam jaringan kewajiban dan hak keluarga yang disebut hubungan peran (role relation). Seorang disadarkan akan adanya hubungan peran tersebut karena proses sosialisai yang sudah berlangsung sejak masa kanak-kanak, yaitu suatu proses dimana ia belajar mengetahui apa yang dikehendaki oleh anggota keluarga lain dari padanya, yang akhirnya menimbulkan kesadaran tentang kebenaran yang dikehendaki.

Anak-anak memiliki dunianya sendiri. Hal itu ditandai dengan banyaknya gerak, penuh semangat, suka bermain pada setiap tempat dan waktu, tidak mudah letih, dan cepat bosan. Anak-anak memiliki rasa ingin tahu yang besar dan selalu ingin mencoba segala hal yang dianggapnya baru, Anak-anak hidup dan berfikir untuk saat ini, sehingga ia tidak memikirkan masa lalu yang jauh dan tidak pula masa depan yang tidak diketahuinya. Oleh sebab itu, seharusnya orang tua dapat menjadikan realitas masa sekarang sebagai titik tolak dan metode pembelajaran bagi anak.

Perkembangan karakter anak dipengaruhi oleh perlakuan keluarga terhadapnya. Karakter seorang terbentuk sejak dini, dalm hal ini peran keluarga 
tentu sangat berpengaruh. "keluraga merupakan kelompok sosial terkecil dalam masyarakat. Bagi setiap orang keluarga (suami, istri, dan anak-anak) mempunyai proses sosialisasinya untuk dapat memahami, menghayati budaya yang berlaku dalam masyarakatnya".

Pendidikan dalam keluarga sangat penting dan merupakan pilar pokok pembangunan karakter seorang anak. Pendidikan wajib dimiliki tidak hanya oleh masyarakat kota, tetapi juga masyarakat pedesaan. Seorang yang memiliki tingkat pendidikan tinggi cenderung lebih dihormati karena dianggap berada distrata sosial yang tinggi. Kualitas seseoarang dilihat dari bagaimana dia dapat menempatkan dirinya dalam berbagai situasi.

Manusia Indonesia yang berkualitas hanya akan lahir dari remaja yang berkualitas, remaja yang berkualitas hanya akan tumbuh dari anak yang berkualitas. Keluarga sebagai lembaga sosial terkecil memiliki peran penting dalam hal pembentukan karakter individu. Keluarga menjadi begitu penting karena melalui kelurga inilah kehidupan seseorang terbentuk.

Sebagai lembaga sosial terkecil, keluarga merupakan miniatur masyarakat yang kompleks, karena dimulai dari keluarga seorang anak mengalami proses sosialisasi. Dalam keluarga seoarang anak belajar bersosialisasi, memahami menghayati dan merasakan segala aspek kehidupan jyang tercermin dalam kebudayaan. Hal tersebut dapat dijadikan sebagai kerangka seiring dengan perkembangan zaman, pendidikan moral dalam keluarga mulai luntur. Arus globalisasi menyerang di segala aspek kehidupan bermasyarakat, tidak hanya masyarakat kota tetapi juga masyarakat pedesaan. Dengan demikian, tidak dapat dipungkiri bahwa peran keluarga sangat besar sebagai penentu terbentuknya moral manusia-manusia yang dilahirkan.

\section{Fungsi Keluarga}

Sebagai sistem sosial terkecil, keluarga memiliki pengaruh luar biasa dalam hal pembentukan karakter suatu individu. "Keluarga merupakan produsen dan konsumen sekaligus, dan harus mempersiapkan dan menyediakan segala kebutuhan sehari-hari seperti sandang dan pangan. Setiap keluarga dibutuhkan dan saling satu sama lain, supaya mereka dapat hidup lebih senang dan tenang”. Keluarga memiliki 
definisi tersendiri bagi orang Jawa. "Bagi orang Jawa, keluarga merupakan sarung keamanan dan sumber perlindungan”. Pengertian keluarga juga dapat dilihat dalam arti kata yang sempit, sebagai keluarga inti yang merupakan kelompok sosial terkecil dari masyarakat yang berbentuk bersdasarkan pernikahan dan terdiri dari seorang suami (ayah), isteri (ibu) dan anak-anak mereka. Sedangkan keluarga dalam arti kata yang lebih luas misalnya keluarga RT, keluarga komplek, atau keluarga Indonesia.

Keluarga menjalankan peranannya sebagai suatu sistem sosial yang dapat membentuk karakter serta moral seoarang anak. Keluarga tidak hanya sebauah wadah tempat berkumpulnya ayah, ibu, dan anak. Sebuah keluarga sesungguhnya lebih dari itu. Keluarga merupakan tempat ternyaman bagai anak. Berawal dari keluarga segala sesuatu berkembang. Kemampuan untuk bersosialisasi, mengaktualisasikan diri, berpendapat, hingga perilaku yang menyimpang. Keluarga merupakan payung kehidupan bagi seoarang anak. Keluarga merupakan tempat ternyaman bagi seoarang anak. Beberapa fungsi keluarga selain sebagai tempat berlindung diantaranya :

a. Mempersiapkan anak-anak bertingkah laku sesuai dengan nilai-nilai dan normanorma aturan-aturan dalam masyarakat dimana keluarga tersebut berada (sosialisasi).

b. Mengusahakan terselenggaranya kebutuhan ekonomi rumah tangga (ekonomi) sehingga keluarga sering disebut unit produksi.

c. Melindungi anggota keluarga yang tidak produksi lagi (jompo).

d. Meneruskan keturunan (reproduksi).

Menurut Kingslet Davis dalam Murdianto (2003) menyebutkan bahwa funsi keluarga ialah :

a. Reproduction, yaitu menggantikan apa yang telah habis atau hilang untuk kelestarian sistem sosial yang bersangkutan.

b. Manitance, yaitu perawatan dan pengasuhan anak hingga mereka memapu berdiri sendiri. 
c. Placement, memberi posisi sosial kepada setiap anggotanya baik itu posisi sebagai kepala rumah tangga maupun anggota rumah tangga, ataupun posisiposisi lainnya.

d. Sosialization, pendidikan serta pewarisan nilai-nilai sosial sehingga anak-anak kemudian dapat diterima dengan wajar sebagai anggota masayarakat.

e. Economics, mencukupi kebutuhan akan barang dan jasa dengan jalan produksi, distribusi dan konsumsi yang dilakukan di antara anggota keluarga.

f. Care of the ages, perawatan bagi anggota keluarga yang telah lanjut usianya.

g. Political center, memberikan posisi politik dalam masyarakat tempat tinggal.

h. Phisical protection, memberikan perlindungan fisik terutama berupa sandang, pangan dan perumahan bagi anggotanya.

Bila seoarang anak dibesarkan pada keluarga pembunuh, maka ia akan menjadi pembunuh bila seoarang anak dibesarkan melalui cara-cara kasar, maka ia akan menjadi pemberontak. Akan tetapi, bila seoarang anak dibesarkan pada kelaurga yang penuh cinta kasih sayang, maka ia akan tumbuh menjadi pribadi cemerlang yang memiliki budi pekerti luhur. Keluarga sebagai tempat bernaung, merupakan wadah penempatan karakter individu.

Pada masa sekarang ini, pengaruh keluarga mulai melemah karena terjadi perubahan sosial, politik, dan budaya. Keadaan ini memiliki andil yang besar terhadap terbebasnya anak dari kekuasaan orang tua. Keluarga telah kehilangan fungsinya dalam pendidikan. Tidak seperti fungsi keluarga pada masa lalu yang merupakan kesatuan produktif sekaligus konsumtif. Ketika kebijakan ekonomi pada zaman modern sekarang ini mendasarkan pada aturan pembagian kerja yang terspesialisasi secara lebih ketat, maka sebagaian tanggung jawab keluarga beralih kepada orang-orang yang menggeluti profesi tersebut. Uraian tersebut cukup menjelaskan apa arti keluarga yang sesungguhnya. Keluarga bukan hanya wadah untuk tempat berkumpulnya ayah, ibu dan anak. Lebih dari itu, keluarga merupakan wahana awal pembentukan moral serta karakter manusia. Berhasil atau tidaknya seoarang anak dalam menjalani hidup bergantung pada berhasil atau tidaknya peran keluarga dalam menanamkan ajaran moral kehidupan. Keluarga lebih dari sekedar pelestarian tradisi, keluarga bukan hanya menyangkut hubungan orang tua dengan 
anak, keluarga merupakan wadah mencurahkan segala inspirasi. Keluarga menjadi tempat pencurahan segala keluh kesah. Keluarga merupakan suatu jalinan cinta kasih yang tidak akan terputus.

\section{Pengaruh Keluarga terhadap Perkembangan Moral Anak}

Papalia dan Old (1987) dalam Hawali (2001) membagi masa kanak-kanak dalam lima tahap :

1. Masa Prenatal, yaitu diawali dari masa konsepsi sampai masa lahir.

2. Masa bayi dan Tatih, yaitu saat usia 18 bulan pertama kehidupan merupakan masa bayi, di atas usia 18 bulan pertama kehidupan merupakan masa bayi, di atas usia 18 bulan sampai tiga tahun merupakan masa tatih. Saat tatih inilah, anakanak menuju pada penguasaan bahasa dan motorik serta kemandirian.

3. Masa kanak-kanak pertama, yaitu rentang usia 3-6 tahun, masa ini dikenal juga dengan masa prasekolah.

4. Masa kanak-kanak kedua yaitu usia 6-12 tahun, dikenal pula sebagai masa sekolah anak-anak telah mampu menerima pendidikan formal dan menyerap berbagai hal yang ada di lingkungannya.

5. Masa remaja, yaitu rentang usia 12-18 tahun, Saat anak mencari identitas dirinya dan banyak menghabiskan waktunya dengan teman sebayanya serta berupaya lepas dari kungkungan orang tua.

Anak-anak sering bertanya tentang banyak hal, baik yang berhubungan dengan hal-hal yang faktual maupun yang fiktif. Pertanyaan-pertanyaan ini, bagi anak-nak, merupakan ekspresi dari rasa ingin tahu dan menyibak keraguannya, sehingga anak tersebut terdorong untuk mengajukan pertanyaan. Hal ini merupakan kebutuhan psikis alamiah yang dinamakan dengan istilah "cinta meneliti".

Cinta meneliti ini merupakan salah satu pertanda anak yang cerdas. Anak cerdas selalu ingin tahu dan terangsang untuk memecahkan masalah yang baru ditemukannya. Dengan begitu, ia dapat mencoba hal-hal baru dan menciptakan produk-produk pemikiran bagi dirinya sendiri. Gardner (2015) dalam Amstring (2005), mendenifisikan kecerdasan sebagai kemampuan untuk memecahkan masalah dan menciptakan produk yang mempunyai nilai budaya. Anak-anak mulai berfikir kritis dimulai ketika mereka menuju pada penguasaan bahasa dan motorik serta 
kemandirian, yaitu pada masa tatih (diatas 18 bulan). Pada masa ini anak-anak mulai mengenal bahasa dan tertarik untuk mempelajarinaya. Berbagai pertanyaan kritis mulai terlontar. Seiring dengan pertanyaan yang keluar dari bibir mungil seorang anak, disinilah peran orang tua bermain. Orang tua dapat menjawab segala pertanyaan anak dengan jawaban yangsebenarnya atau jawaban fiksi yang merupakan karangan orang tua. Orang tua dituntut untuk dapat memberi jawaban yang dapat memuaskan hati seoarang anak, sekalipun jawaban itudirasanya sanagat sulit dipahami oleh anak karena pertanyaannya yang bersifat sensitif. Berawal dari pertanyaan-pertanyaan dari seorang anak, pendidikan meneganai moral dan budi pekerti dapat ditanamkan.

Penanaman moral pada diri seoarang anak berawal dari lingkungan keluarga. Pengaruh keluarga dalam penempaan karakter anak sangatlah besar. Dalam sebuah keluarga, seoarang anak diasuh, diajarkan berbagai macam hal. Diberi pendidikan mengenai budi pekerti serta budaya. Setiap orang tua yang memiliki anak tentunya ingin anaknya tumbuh dan berkembang menjadi manusia cerdas yang memiliki budi pekerti baik agar dapat menjaga nama baik keluarga. Anak bukanlah orang dewasa, ia memiliki sifat-sifat yang khas. Seorang anak melihat, mendengar, berperasaan, dan berfikir dengan bentuk yang khas, namun tidak keluar dari logika dan perasaan yang sehat. Misalnya, anak-anak itu melihat, mendengar, dan berperasaan sebagaimana orang tua melihat, mendengar, berperasaan dan berfikir. Karena itu, oarang tua seharusnya mempergauli anak-nak berdasarkan pada anggapan bahwa dia adalah anak-anak. Sebagaimana dikatakan, "Pemuda tidak akan menjadi pemuda yang sebenarnya selama masa kanak-kanaknya tidak menjadi anak-nak yang sebenarnya".

Keluarga memberikan pengaruh pada pembentukan budi luhur bagi seorang anak. Salah satu ciri anak yang berbudi luhur adalah selalu menunjukkan sikap sopan dan hormatnya pada orang tua. Budi luhur yang melekat pada setiap orang bukan datang dengan sendirinya, melainkan harus diciptakan. Terutama dalam keluarga dan bukan merupakan keturunan. Dengan kata lain, budi luhur tidak merupakan keturunan melainkan merupakan produk pendidikan dalam keluarga, merupakan perpaduan anatara akal, kehendak dan karsa. Seiring dengan 
perkembangan zaman, terjadi pergeseran nilai-nilai kebudayaan pada masyarakat. Siaran-siaran televisi kembali menjadi salah satu faktor penyebab lunturnya nialainilai tersebut. Hadirnya telivisi telah merebut perhatian anak terhadap orang tua. Anak seringkali mengabaikan nasihat yang diberikan oleh orang tua dengan alasan nasihat tersebut terkesan kuno. Dalam kondisi demikian, seorang anak tidak mengetahui yang sebenarnya mengenai nilai-nilai yang seharusnya diberikan orang tua kepada anaknya.

Pada masa sekarang, intensitas bertemu antara anak dengan orang tua sangatlah sempit. Oleh karena itu, orang tua harus mampu membagi waktu dengan baik dan mencari saat-saat yang tepat untuk menyelipkan pelajaran mengenai budi pekerti luhur. Pada saat makan malam misalnya, atau pada saat menonton televisi bersama, sambil membimbing. Kejujuran merupakan hal terpenting bagi individu dalam menjalani hidup, dan tahap awal penanaman sikap jujur dimulai dari keluarga. Penanaman sikap jujur dalam keluarga dapat dimulai dari perilaku orang tua yang selalu bersikap dan berkata jujur. Dengan begitu, maka akan lebih mudah bagi seoarang anak menanamkan sikap jujur pada dirinya karena tidak pernah merasa dibohongi. Dalam suatu keluarga, tidak dapat dipungkiri bahwa sesekali seorang anggotanya melakukan kebohongan. Seseorang melakukan suatu kebohongan biasanya disebabkan oleh rasa takut karena dianggap melakukan kesalahan atau sedang menyembunyikan sesuatu. Dalam banyak hal, sebaiknya orang tua mendengarkan pendapat anaknya, karena bagaimana pun komunikasi dalam keluarga harus tetap berlangsung dengan baik.

\section{Peran Keluarga}

Keluarga memiliki peranan utama dalam mengasuh anak, di segala norma dan etika yang berlaku didalam lingkungan masyarakat, dan budayanya dapat diteruskan dari orang tua kepada anaknya dari generasi-generasi yang disesuaikan dengan perkembangan masyarakat. Keluarga memiliki peranan penting dalam meningkatkan kualitas sumber daya manusia pendidikan moral dalam keluarga perlu ditanamkan pada sejak dini pada setiap individu. Walau bagaimana pun, selain tingkat pendidikan, moral individu juga menjadi tolak ukur berhasil tidaknya suatu pembangunan. 
Perkembangan ilmu pengetahuan dan teknologi memegang peranan penting serta sangat mempengaruhi perkembangan sikap dan intelektualitas generasi muda sebagai penerus bangsa. Keluarga kembali mengambil peranan penting dalam peningkatan kulaitas sumber daya manusia. Berbagai aspek pembangunan pembangunan suatu bangsa, tidak dapat lepas dari berbagai aspek yang saling mendukung, salah satunya sumber daya manusia. Terlihat pada garis-garis besar haluan negara bahwa penduduk merupakan sumber daya manusia yang potensial dan produktif bagi pembangunan nasional. Hal ini pun tidak dapat terlepas dari peran serta keluarga sebagai pembentuk karakter dan moral individu sehingga menjadi sumber daya manusia yang berkualitas.

Keberhasilan pembangunan suatu bangsa sangat memerlukan adanya sumber daya manusia yang berkualitas baik. Untuk mendapatkan sumber daya manusia yang berkualitas baik tentunya memerlukan berbagai macam cara. Salah satu diantaranya adalah melalui pendidikan. Pendidikan baik formal maupun informal. Pendidikan moral dalam keluarga salah satunya. Walaupun memiliki tingkat pendidikan yang tinggi, tetapi rendah dalam hal moralitas, individu tidak akan berarti dimata siapa pun. Pendidikan moral dimulai dari sebuah keluarga yang menanamkan budi pekerti luhur dalam setiap interaksinya. Sumber daya manusia berkualitas dapat dilihat dari keluarganya. Bukan hanya keluarga mampu dari segi materi, yang dapat meningkatkan kualitas individunya melalui tambahan-tambahan materi pembelajaran di luar bangku sekolah. Akan tetapi, keluarga sederhana di desa pun dapat menjamin kualitas sumber daya manusianya. Kualitas sumber daya dan keluhuran budi pekerti merupakan hasil tempaan orang tua.

\section{Kesimpulan}

Keluarga merupakan suatu sistem sosial terkecil yang didalamnya dapat terdiri dari Ayah, Ibu, dan anak yang masing-maing memiliki peran. Anak merupakan buah dari keluarga bahagia. Anak-anak memiliki pemikiran kritis akan banyak hal dimulai ketika ia mulai mengenal bahasa. Pertanyaan-pertanyaan yang terlontar dari mulut seoarang anak sebaiknya dijawab dengan jawaban yang jujur dan dapat memuaskan hati anak. Pendidikan moral dan kejujuran bagi seoarang anak berawal dari keluarga, melalui orang tua. Hal ini dapat membentuk karakter anak di masa depan. 
Orang tua merupakan panutan bagi anak-anaknya, untuk itu sebaiknya orang tua dapat menjadi contoh yang baik bagi anak-anaknya. Orang tua juga harus membuka diri terhadap perkembangan zaman dan teknologi saat ini. Anak-anak memiliki pemikiran yang kritis terhadap sesuatu yang baru. Bila orang tua tidak membuka diri terhadap perkembangan yang ada, kelak akan menuai kesulitan dalam menjawab pertanyaan dari anak. Pada akhirnya berubah kebohongan dan secara tidak langsung menanamkannya pada anak.

\section{Daftar Pustaka}

Armstrong, Thomas. 2005. Setiap anak Cerdas. Jakarta : PT. Gramedia Pustaka Utama

Effendi, Suratman, Ali Thalib, Wijaya, Dan B. Chasrul Hadi. 1995. Fungsi Keluarga Dalam Meningkatkan Kualitas Sumber Daya Manusia. Jambi: Departemen Pendidikan dan Kebudayaan.

Geertz, Hildred. 1983. Keluarga Jawa. Jakarta: Grafiti Pers.

Goode, William J. 1983. Sosiologi Keluarga. Jakarta: Bina Aksara.

Gunarsa, Singgih D. Menyikapi Periode Kritis Pada anak dan Dampaknya pada profil Kepribadian tahun 2001 dalam Psikologi Perkembangan Pribadi dari bayi sampai lanjut usia. Editor: S.C. Utami Munandar. Jakrta: UI Press. 2001.

Hawadi, Reni Akbar, 2001. Psikologi Perkembangan Anak. Jakarta: PT. Grasindo.

Mudjiono, Hermawan, Hisbaron, Noor Sulistyo, dan Sudarmo Ali. 1996. Fungsi Keluarga Dalam Meningkatkan Sumber Daya Manusia. Yogyakarta: Departemen Pendidikan dan Kebudayaan.

Munandar, Utami. 1983. Emansipasi dan Peran Ganda Wanita Indonesia: Suatu Tinjauan Psikologis, Depok: UI Press.

Murdianto, Utomo, Bambang S. 2003. Modul Mata Kuliah Sosiologi Pedesaan. Bogor: Jurusan Sosial Ekonomi Pertamina, Fakultas Pertanian IPB.

Zurayk, Ma'ruf. 1997. Aku dan Anakku. Bandung: Al-Bayan (Kelompok Penerbit Mizan) 